$$
\operatorname{sen}-14.58
$$

UC.46

Reporting Date: March 1975 Issued: May $\mathbf{9 7 5}$

\title{
Capsule Storage and Density-Analog Techniques
}

by

H. C. Paiton

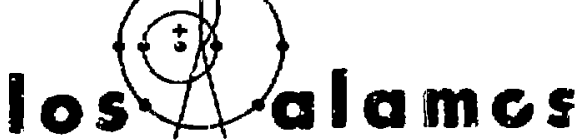

soigmtific daboratory

of the University of Colifornio

LOS ALANSOS, NEW MEXICO 87544

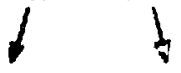

An Alfirmulive Action / Equol Opportunity Emplayes 
Printed in the Unitod Statev of Amenca Avaulable from Netional Technical Intormation Service

US Deportment of Commarce

5285 Port Royal Rood

Price Printed Copy $\$ 4$ to Microtiche $\$ 2.25$

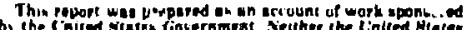

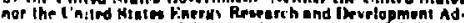

ministration. nor ans of theite eniplosert. nor ans of the ir con.

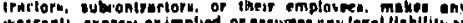

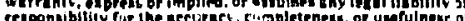

entongibinfy

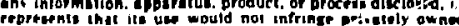

inht. 


\section{MOTice}

This teport' was prepared as acount of "wort This report was propater Covernonent. Neither sponcored by the Unted She United States Eneroy the Uated States nor the United states nor any of

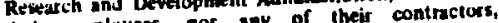
their employees, nor any of their contract any

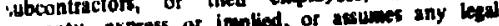
wartanty, express of linplid, or ary, completeness liablity of respontibing for the scuracy, complestuct as or uesulmes of sny informution, apparatum product ar procese diccloeed, of tepesents that its we would not infrine privately ownod tights.

○

CAPSUIEE STORAGE AND DENSITY-ANALOG TECHNIQUES

\author{
by \\ H. C. Paxtan
}

ABSTRACT

Dansity-analog schemes for describing critlcal arrays of plssile units have a long history. They orleinated as methods for generalizinf results of subcrlt1cal measurements on weapon capsules. Such measurements were needed to establish reasinably efricient rules for capsule storage. Although spec1fic density-analog models have been Improved throuchout the years, they are now iargely replaced by comprehensive tabulations of critical-lattice parameters. Certain simplified forms are still useful as convenient formulas for extrapolation or for gross sorting 37 safety features.

\section{INTRODUC:ION}

In the 1940's the need to store massive weapon capsules led to density-analop. schemes for representing arrays of fissile units. To keep the scale of storage fac1l1t1es under control, it was necessary to Fenerallae the resuits of stitcritical "vault tests" that were undertaker at the los Alamos selent 1fle Laboratory (LASL) in 1947.' Recert declass1flcation of Information about these tests and about subsequent measurements involving weapon componerts allows us to review the hlstory of density-analog tecrniques. It. aldition to expla1r:1ne the orle1s ard appilsat ions of these technlques, we point out the extent. to whleh they have been dlsy.laced by prealse representations of crltical arrays, and surpest ways in whtoh they car still le lisefli?.

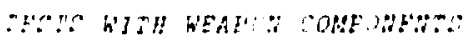

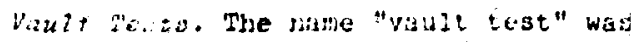

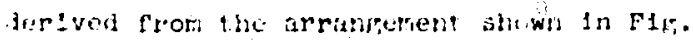

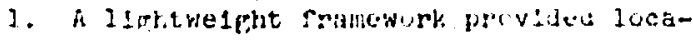

tions for as many as 27 capsules in a cublc array, whlch could be surrounded completely ty concrete. The frumework was in two parts and was mounted en tracks so. that the two portions, with part of the concrete, could be withdrawn In opposite directions. A scram sinnal automatically actuated the withdrawal, and, it was possible to reassembie remotaly. Concrete wails and roor were I ft thick and tine rloor was of 6-1n.-thick reinforced corcrete. The Interior dimension of the cuble vault could be adjusted to 3, 4, or 5 rt: spacinss provided by the framework could be adjusted to correspond.

Bas1c components, called "rissile un1ts," were U(9,)-Pu comblnations, each equivalent 1 r: reactivily to a sphere or about 20 ke $U(93)$. An entlre capsule, called a "tamped unis," was a rissile unlt surrounded by natural urirtun vary1np 1 n thickress from to $2 k$ in. Neutron-mult1pl10aLIon values were measured as adjacent latilce positions were rilled propressively by rissile units, then by tamped units, and rlally by rissile unita opened into halves. 
Jets of curves for the fissile units appear In F1s. 2, along with results of later measurements on smaller vaults. All reclprocalnultiplication curves were extrapolated to critical1ty, although results for the larger vaults were highly fictitlous. The crossmultiplication curves $\left(M_{x}\right)$, which are normalized to unity for asingle unit, are reasonable representations of interaction." An arbltrury rule, adopted for all storage arrays, is that the overall value of cross multiplication should not exceed two.

To provide a basis for generalization, extrapolated eritical data from these tests were represented as in Fis. 3. These results apply to fully reflected arrays, and simllar curves were obtalned wher vault wails and top were removed. The apparent power relationships between critical number and lattlce density.

$\because c=$ const $p^{-B}$

suggested the relation for the critical mass of a single unit as density is changed uniromity

$\pi=m_{c o}\left(p / o_{0}\right)^{-s,}$

where rco is the critical riss at fuld der:sity $D_{0}$. Because of this sinilarity, the terr. "density analog" was applied to relation (i).

reots with Larger Capaules. Some years arser the vault tests, other subcritical reasurements were made on arrays of larger adrium-plated $\mathrm{C}(93)-\mathrm{Pu}$ capsules, each equivalent in reactivity to a sphere of about $32 \times 5$ U(93). Results for large arrays of 3uch units 1n 16-in.-square by 25-1n.-high enrtalners weru reported by schuske or Dow Chemleal Company's Rockj Flats Plant. 2 ' Although tests were diracted more toward practscal storage arrangements than 1deallzed lattices, some extrapolated data were jeruced for cublc arrays. Fleure 4 gives :jFlcal results for planar (two-dimensional) arrays of these units on a concrete floor. With a Iittle imagination these data could be extended to glve the critical spacing for an infintte planar array: The curresponding surface density, along with similar results for large low-density units, 2 suggested the surrace-dens1ty' correlation of F1g. 5.0 (It should be noted that general validity of the "suggested storage $11 \mathrm{mi} i$ " has been disputed.)

As expected, reciprocal cross-multipl1cation curves for IInear (one-dimensional) arrays of the large capsules level out at smal?er numbers than do the corresponding curves for planar arrays. Figure 6 gives such a comparison for 16-in. spacings.

Out of these measurements and densityanalog extrapolations grew general rules for criticailty control in the storage of capsules and enrfched-urantum components of gur-type weapons. These rules persist, desplte the fact that they could be refined in terms of recent informatoon, such as that ir. "Culde for Criticality Control in the Storage of Fissile Materials." The storape $11 \mathrm{~m} 1 \mathrm{t}$ follow.

\begin{tabular}{|c|c|c|c|c|c|}
\hline $\begin{array}{l}\text { Type of } \\
\text { Array }\end{array}$ & $\begin{array}{l}\text { Minimum Cent } \\
\text { to-Center Sp }\end{array}$ & $\begin{array}{l}\text { er- } \\
\text { acing }\end{array}$ & $\begin{array}{r}\text { AI } \\
\text { Numbe }\end{array}$ & $\begin{array}{l}\text { l lowab: } \\
\text { er or }\end{array}$ & $\begin{array}{l}\text { Ue } \\
\text { Units }\end{array}$ \\
\hline IInear & 16 In. $(40.6$ & $\mathrm{cm})$ & no & $11 \mathrm{~m} 1 \mathrm{t}$ & 3 \\
\hline planar & $=24 \mathrm{ln} .(61.0$ & $\mathrm{cm}$ ) & no & $11 \mathrm{~m} 1 \mathrm{t}$ & \\
\hline$"$ & $21 \pm n .(53.3$ & $\mathrm{cm})$ & $\therefore$ & 50 & \\
\hline " & 16 in. 140.6 & $\mathrm{~cm})$ & & 32 & \\
\hline volume & 36 In. $(91.4$ & $\mathrm{cm})$ & & 40 & \\
\hline " & $30 \mathrm{ln} .(76.2$ & $\mathrm{cm})$ & & 30 & \\
\hline$n$ & $24 \mathrm{ln} .(6) .0$ & $\mathrm{~cm}$ ) & & 20 & \\
\hline$\mu$ & 20 1n. 150.8 & ent) & & 12 & \\
\hline
\end{tabular}

Rather arbltsar $11 y$, arlays such as those listed were consldered 1solated from one another if more than 13 ft apart or separated by concrete at least 1 ft thick. Add1tional subcritical measurements were made on large capsules arranged in more practical storage conflgurations, such as that of two facing planar arrays separated by varlous distances (FIg. 7). Each plane contalred 12 capsules spaced 30 in. 
center-to-center. As the reciprocal crossmultiplication curve shows, Interaction between planes $1 \mathrm{~s}$ small when they are separated by more than $10 \mathrm{ft}$. At a separation of $6 \mathrm{ft}$, the multiplication was not affected by the persons shown in Fig. 7 , standing as they might in the corridor of a storage vault.

Similar measurements on larger numbers of the same capsules in an actual storage vault are described by F1g. 8 . If cross multiplication were not allowed to exceed two, the permissible number of these units would be about 25 at 19-1n. center-to-center spacing and 50 at 2l-1n. spacing. When rour people stood in the corridor, neutron counting rate actually was noduced somewhat. There was no measurable effect from the 11lustrated 25 units in a ne1ghboring enclosure separated by a 12-1n,-thick concrete wall.

The last two series of tests led to the concept of "associated arrays" consisting of two facing planar arrays separated by less than $13 \mathrm{ft}$. Th1s concept was used in speclal rules applicable to capsule storage in cramped quarters, such as on shipboard. Modifled rules for assoclated arrays are as follows.

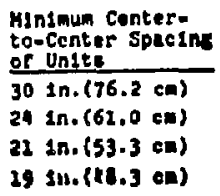

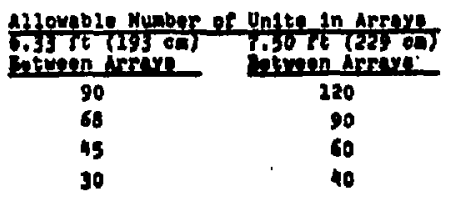

These limits also could be reflned, but have served well enough as they stand.

Flooding reat. Although cadmium plat... ing would protect against criticality if only one of the jarge capsules should be rlooded, there was some question about the efiect of rising water on an array of such capsules in their contalners. Again, shipboard storage compartments were of princ1pal concern. Because the contalner consists of a relatively small cylinder within a tubular framework, or "birdcage," units In a flooded array would be isolated by large water thicknesses. But effects of partlal flooding were not well known, so an experiment with the setup shown in F1g. 9 was undertaken at LASL. A tank containing e1ght units in contact was surrounded by concrete walls and closed on top by boxes of parafin. As the water level rose in the tank, neutron response differed little from that expected for a single unit.

\section{WEAPON STORAGE}

One of the blggest hazaris in the storage of complete 1mplosion-type fission weapons is the conventional explosive. In most such weapons the explosive is effective in preventing criticality, but, of course, introduces risks of $1 \mathrm{ts}$ own. In our exper1ence, a $4-1 n$. thickness of explosive between nuclear components of fission weapons (2 in. per weapon) provides a neutron ahielo that w1Il prevent critlcallty for unlimited storage in any arrangement.

For a few weapons of the f1ssion-fusion type, ther: are iestrictions on numbers that can be stored in volume (three-dimensional) arrays. For some of these weapons, special subcrit1cal measurements were made to estab11sh or confirm permissible storage arrangements. Incldentaliy, in no case was there a restriction on I1near or planar arrays of such weapons in their usual contalners. one set of tests explored the safety of the two-h1gh arrangement (F1g. 10) which would conserve deck space on ship. The results, given in F1g. 11, show that the length of this array could be extended indefinitely without exceeding a cross-multiplication value of two. They further demonsirate the negligible effect of another unit that might be above the array while being moved into 1ts proper location.

Mo. of the experiments described above would be unnecessary today. To a large extent, powerful computational techniques, auch as Monte Carlo, with large banks of experimental data fon vallatior, would take 
the place of aubcritical testa, of course, there remaina the pcasib1lity of measureinents for the purpose of conflrming questlonable computed mangino below criticality.

\section{EVOLUTIOA OF DEASITY AAALOG TZCRAIQUTS}

Initial Danatty-Analog Formulation.

In the course of weapon arit smponent testa a rather apeciflc modsl for critlcal arraya was hypothesized and became known as the density-analog method, Although published elsewhere, a review of th1s scheme, with 1t: abaequent Improvenents, and 1ta shortcominge, flte 1nto thit discusalon.

The nypothesis wse that the $1 \mathrm{mple}$ extrapolation formula of relation (1) could be turied into a more aneciflc expression patterned after (2). Nemely, it was assumed that the critical mass of a cublc array could be expresied is

$M_{c}=m_{c o}\left(\bar{p} / \rho_{0}\right)^{-s}$,

where $m_{c o} 18$ the critical mass of a cube or the risalle material at rull density po" reflected like the array. Conservative interpretations of subcritical measurements, Including those discussed above, suggested the following correjations between the exponent and the "ripaction critical" of a unit $r:$

- 2(1-r) for unreflected arrays,

s $=1.4(1-r)$ for heav1ly reflected arrays.

The quantity $f 18$ the same as that in Fig. 5. Th1s model gives the rollowing simple expression for a reflected array for which $f \sim 0.3:$

$M_{c}(\operatorname{rerl})=m_{c o}(\operatorname{rerl}) \rho_{0} / \rho^{-}$

As early as 1960, it was observed that the critical date for arrays (as opposed to subcrit1cal data) gave values of $s$ that did not 11 the above expressiors very well.

Those results, obtalned from near-equilateral critical clustera of solution containers, appear as the devient points in F1G. 12.

Modified Formulations. D. R, Sm1th rerognized that the value of s for extremely large reflected arrays mut approach that for unreflected arrays of 31 milar units, as 1s the extreme case for density exponents or 1solated bare and rerlected spheres. The 1mplication, of course, is that relation (4b), laplying a constant value of $a$ for reflected arrays, is not a good model.

To Improve mattera, Sm1th cont1nued to use expressions ( 3 ) and (4a) ror inreflected arraya, but applied a computed "reflection factor" $A$ to obtain the critical mass of the corresponding reflected array. Thus the resulting criticnl mass was expressed by

$M_{c}(\operatorname{rer} I)=\left[m_{c o}(\operatorname{are}) / R\right]\left(p_{0} / \bar{p}\right)^{2(1-r)}$.

Smith also computed the following values of R for various homogeneous systems at very low densities.

LIMITING RATIOS OF CRITICAL MASSES OF BARE AND WATER-REFLECTED SPHERES AT LOW DENSITY

Core Composition

$\mathrm{v}(93)$ metal

$\mathrm{U}(93) \mathrm{O}_{2}$

$\mathrm{U}(93) \mathrm{F}_{6}$

$U(93) C_{80}$

$\mathrm{U}(93)$ olution, $\mathrm{H} / 235 \mathrm{U} \cdot 60$

$\mathrm{U}(93)$ solution, $\mathrm{H} / \mathrm{r}^{235} \mathrm{U}=400$

Pu metal

Somewhat later, when more became known about crit1cal cub1c lattices, T. T. Thomas' pointed out that for a st111 better approxImation the constant value $s=1.8$ could be adopted for all large cublc arrays of practical-size units. He suggested that the density-analog concept be used only for extrapolating to smaller $\bar{p}$ rrom an experimental 
(or complted) crltical array of reasonable slze, lnstead of crom a full-density crit1.a: mass. It rolicws that the simple extrapolation cormula ( $\downarrow$ ) becomes

$n_{c}=A\left(\rho_{0} / \bar{p}\right)^{1.8}$,

where the constart $A$ is evaluated in terms $0:$ the critical values of $\|$ and $p_{0} / \bar{p}$ for a kr.wre reference array of the same untts.

Cesto o: Rensity-Anoiog sehemea. The role of der.stty-analor models is influenced profoliddy ty the reliable parameters that ex:s: now sor a great vartety of critleal

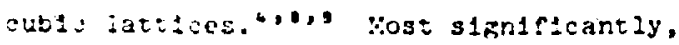
rellaree dpon such ractels has all but disapteared, althouth the simple. roms st1?: have thefr place as corventent romias for exteapolation or for fross sort1ri of safe-y leatures. Eeculdse of these res!dua: ues, we copea: here eviluatons or she par-

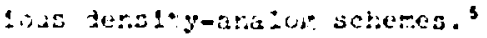

Eosulta of these schenes are sompared

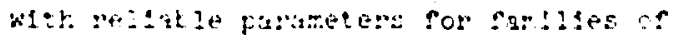

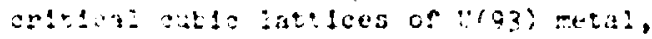

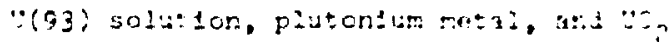

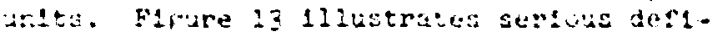

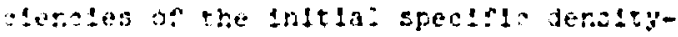

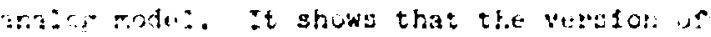

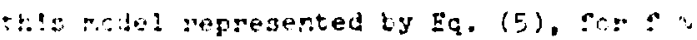

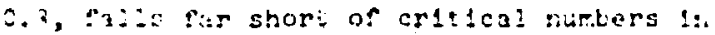

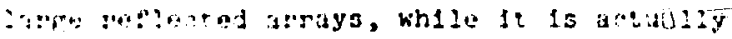

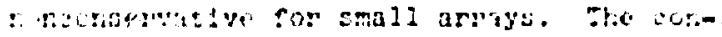

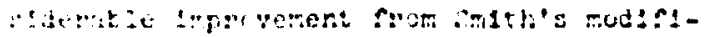

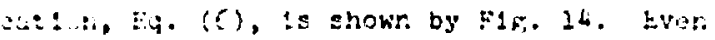

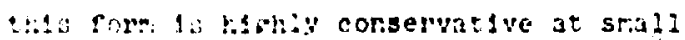

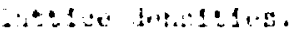

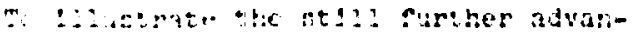

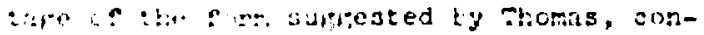

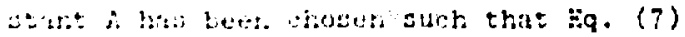

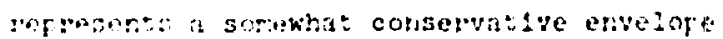

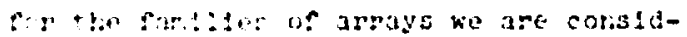
"rli,e. Pry itse purpese, the value or A

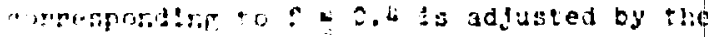

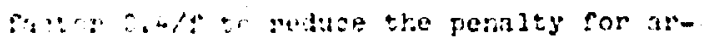
ay of lose rezcsive und:s. Equation (7) ther teeordes
$N=(0.012 / r)\left(0_{0} \sqrt{p}\right)-1.8$ for $f \leq 0.4$, whlch is represented in F'1f. 5 , toEther with the reference familles or lattlces. Although this is the best of the spec1ric density-analog forms, it ls not simple enough to be an easily remembered substitute for the extensive tabulations that Thomas has provided."

Denoity-fnalog schemps at fest. Density-analof methods have served aceeptab:y during our period of ignorance about marneters of larpe critical latt1ces, kut the comprehersive tatulat1crs that appear in Rer. 4 are rore rel1atle and as easy to lise. The density-analof corcept persists 15 the simpie extrapolattch formis :Eq. (7):

$:_{c}=$ cons: $\left(f_{0} / \bar{\rho}\right) ! .:$,

wh:ch froytdes a tandy mears ol exiendinf krown suticaltty data. Althoukh we recin reazize itat it 1 e extremely sude, another very stmpie expression (Eq. (5):

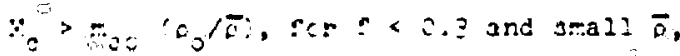

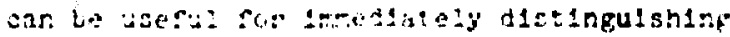

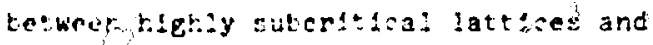
those hat equiri bot:er evaluat:on. These tens:ty-aralof, rrapmen:z are al! that we reconsicsif retalritr.

a PInal ohservat :ci: :s that dene:tyaralor ftciures of cubts atities do not extend read1ly to the nope laphaziand layouss that are cusiorary 1n recsesalfo flarts.

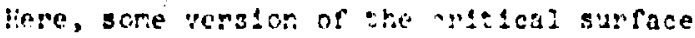
deresty comoct 1repoduced in F1E. E $1 \mathrm{~s}$ factibiy mone applicable.'0

\section{REFEREW:S}

i. E. C. Mallary, H. C. Faxtor, R. H. White, "Sarety Tests ror the Storage of Plusile Un1ts," Los alamos Sclentific Laboratory report LA-IQ75 (February 1955).

2. C. L. Schuske, "Jeutron Mult1plication Measurements or Oralioy inits in Array3," Dow Chemicaj. Co., Rocky Flats refort RFP-51 (June 1955). 
3. C. I. Schuske, "Neutron Multiplisation Measurements of ParalleI Arrays or oral10y Units," Dcw Chemical Co., Rocky Flats refor: RFP-59 (February 195E).

- Arrevean Natlchal Jabudard, "Gulde for En1t:sa:1:j Safety in the Storaze of Etssile Yatertals," ANST :16.5-\$973.

‡. H. C. Paxtor "Dens!ty-inalog Techniques," In Froc. Eiverrore Array Symcos1uT., I1 venore, Un, Sept. $23-25$. T965; USAEC report :0:8F-690909, pp. $E=12$.

6. E. E. Sm1:h, "oriteria ard Evaluat 10 ror the Storage of Elssize Yateria! in a Earze and Varled Reactor Propramme," Ir. Cri:1cal1:y Cortrol of Fiss1le MateFials, Proc, Symp., Stockholm, Nov. I-5, I965; interr. htonsc Enery fzer.cy Proz. Sertes (SEI,PLE/I14), Vlerna, 196E, FP. $657-675$.
7. J. T. Thomas, "Cr1t10e11ty of :7"Fe Systems of Subcritical L(93) Conponents," Car Rtage Naticnal Latoratory Crlt callty Data Center report oR:L-CDCI (Aligust 1967).

8. H. C. Faxton, "Cr1:1cality Control In Operastors witl: Fisslie Materlal, "w口 ijarios Selent 1fis Labcratory report :A-336E(Rev) (:Hoverter 1972 ), see refererices therein.

9. 3. T. Thomas, "Cr!t_cal Theco-Dtrer-

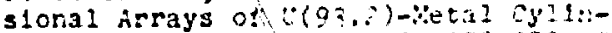

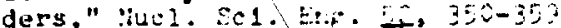
$(\div 9 \div 3)$.

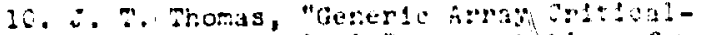

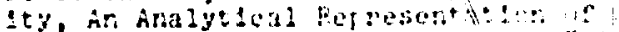
Ferlected Arriys or pisesle "atus," ar

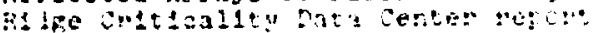
Y-.DC-13 (nutus: $197 \%$ ). 


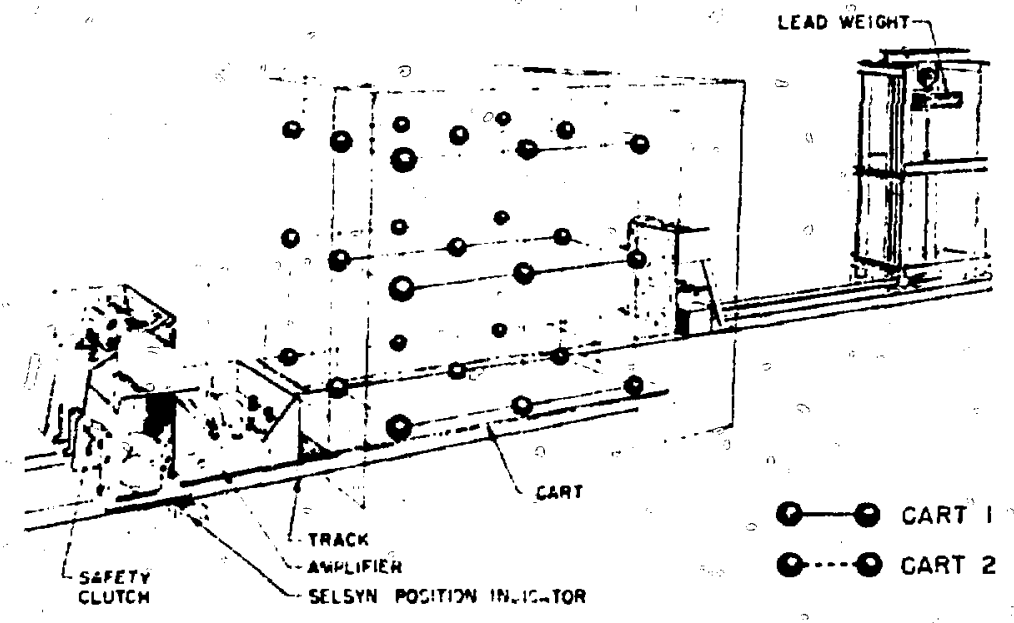

Fle. i. Stive for vault tests of 1947.
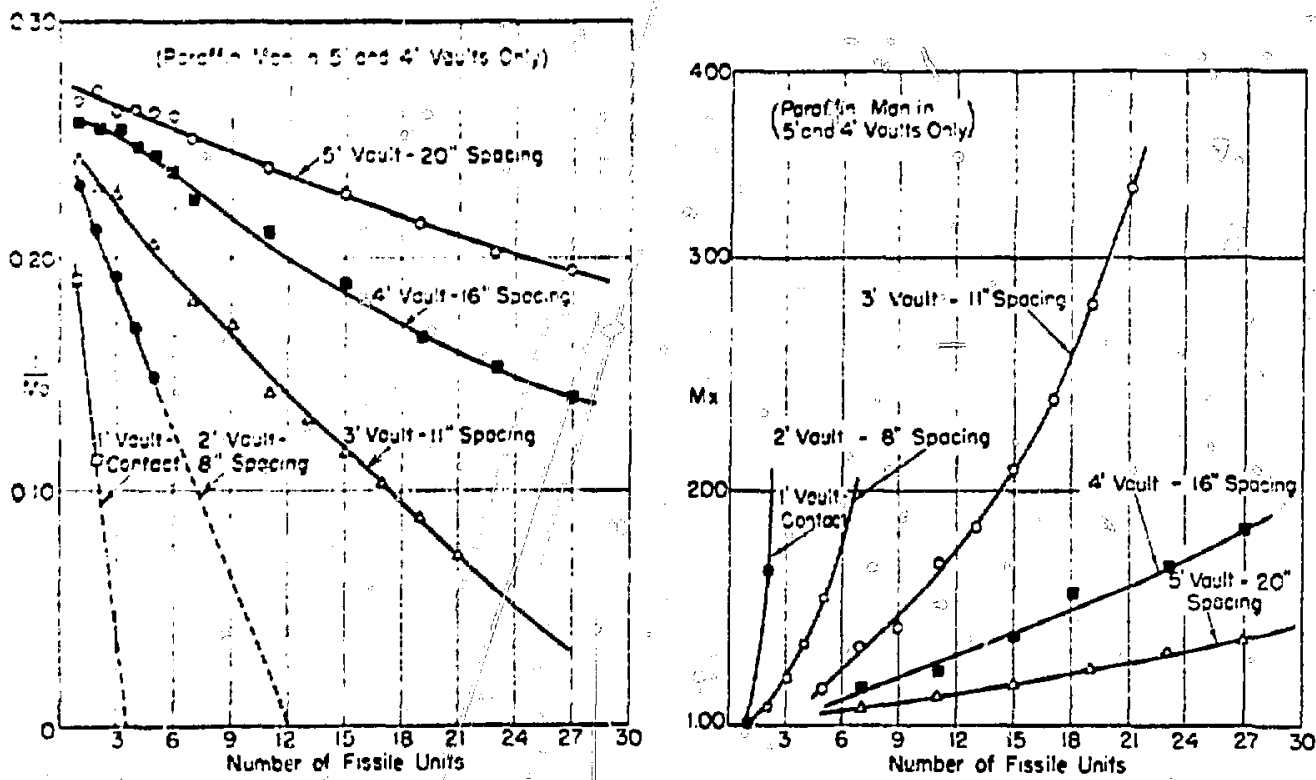

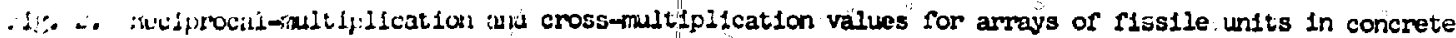
fuluito. 


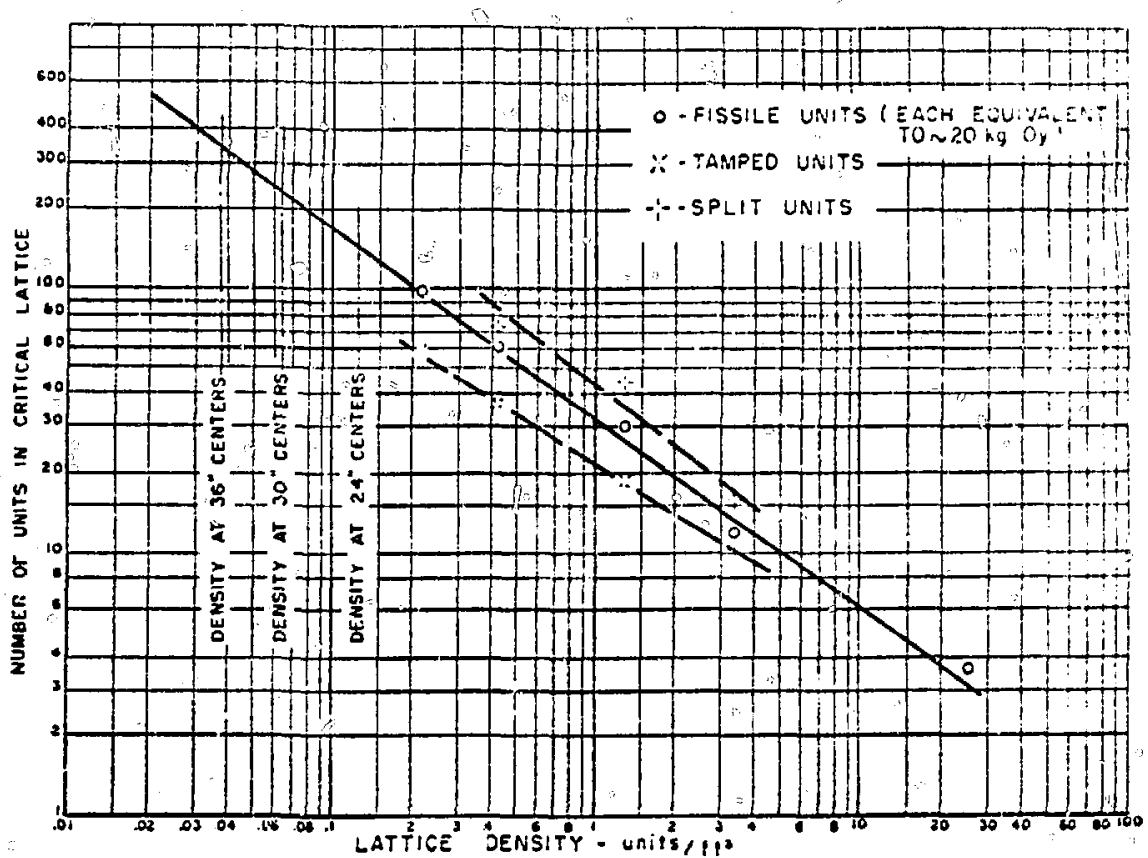

i1g. 3. txtrapolated critical uata for arrays of weapon compunents in ccincrete valuits.
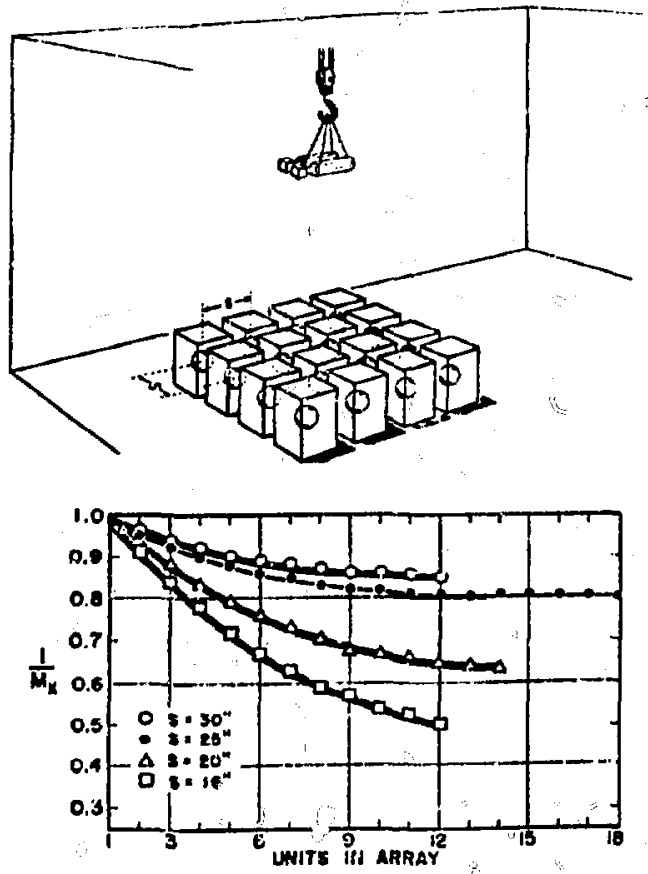

HL. 4. Planar array of large capsules; neutron counters are overinead. I'ne reciprocal cross-multiplication curves are for verlous alues of centar-tomenter spacinfi.

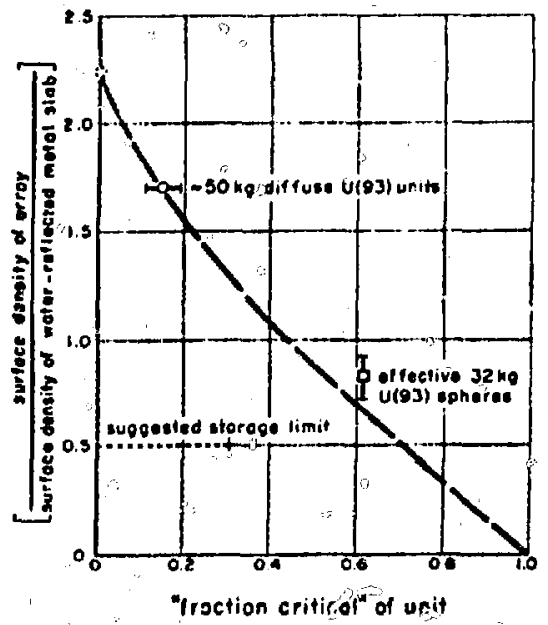

HE. j. Extrapolated erltical surface donsities for Infintte plasiar arrays of large capsules and massive low-density untts. The abscissa 15 the ratio of the mass of a undt to tiat of a inilar critical init. 


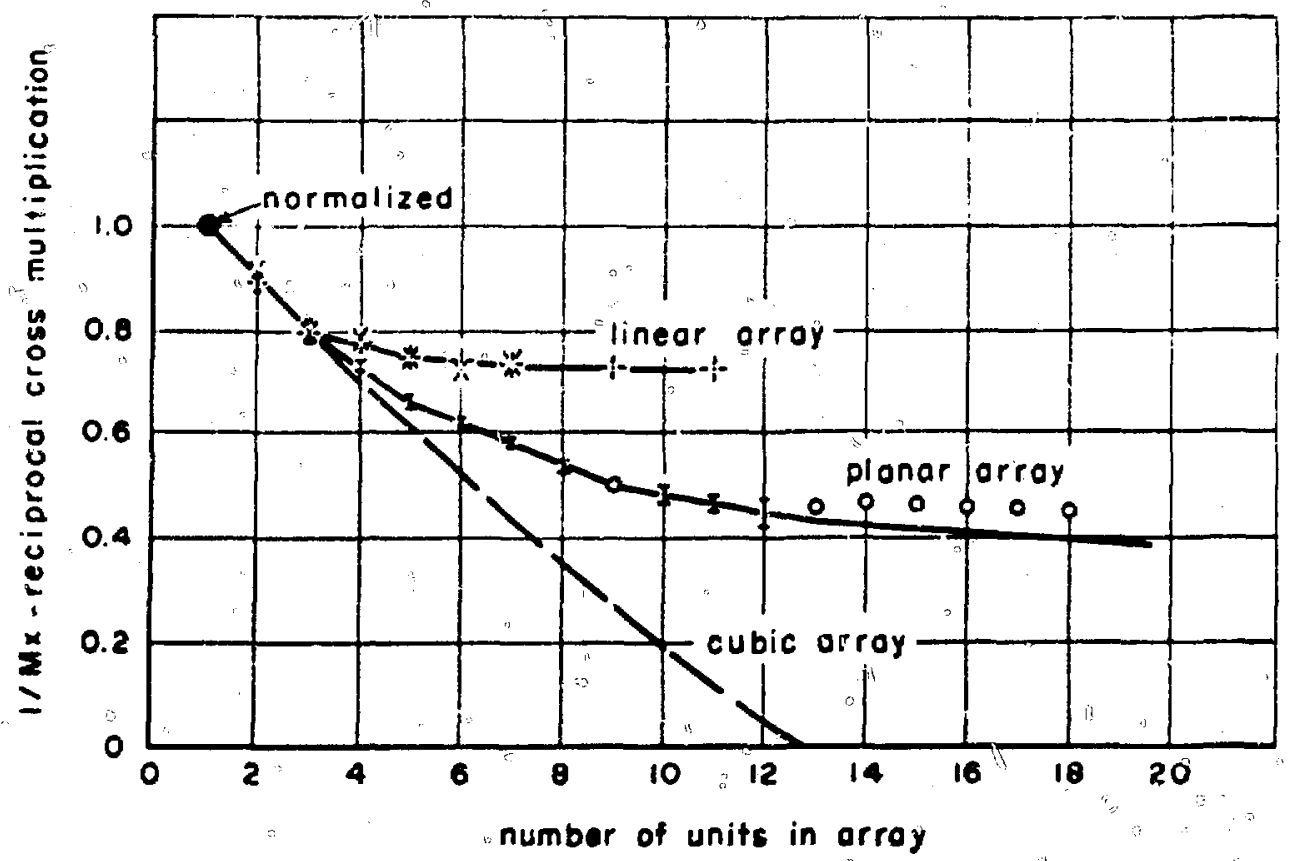

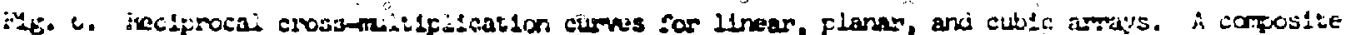

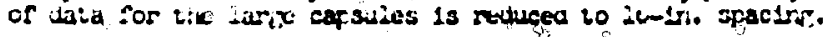

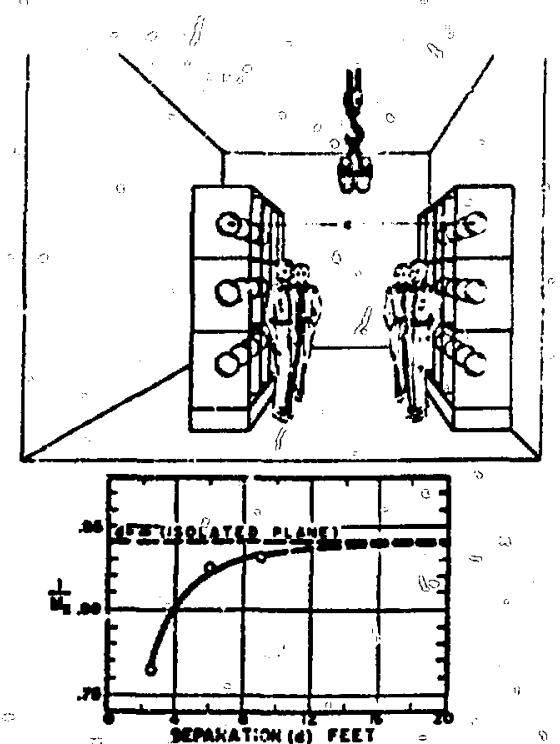
F1E. 7. Eizct of separation between two planar
arrays on ovezali cross miltiplicatior.. arrays on ove:ali cross multiplicatior.: at $30 \mathrm{~m}$ 1n. spac1nt; neutron counters were overnead. Fersins betwech planes afu root charge resulte.
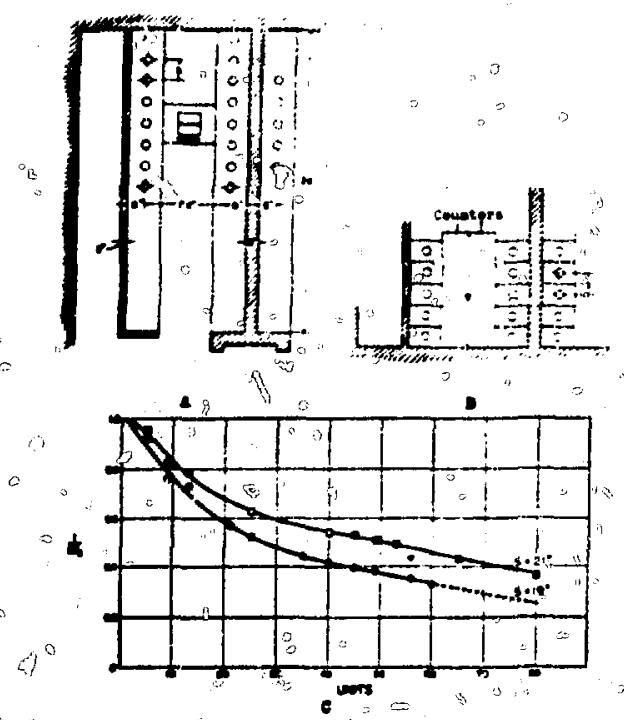

19." C. Ciange of reciprocal cross muliplication as large capsules were positioned in a storage vault at spactings of 19 and 21 in. une sice was filled before the otixer was started. The lonesone point, for 19-1n. spacings snows the apparent erfect of four persons in the corrficor. 


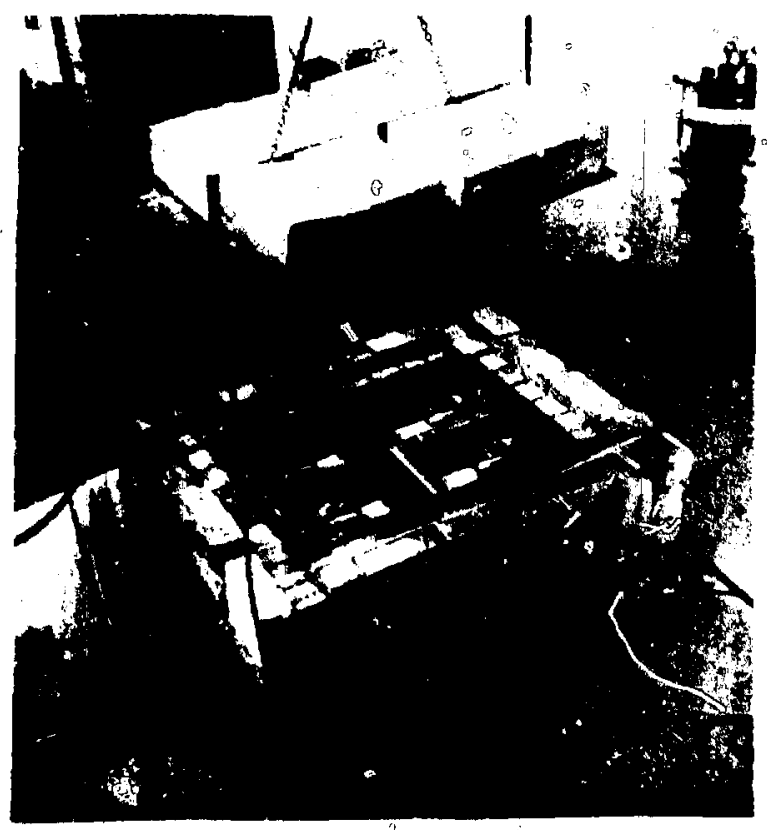

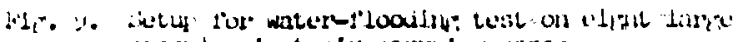
eipuless lit treile camylin: cusses.

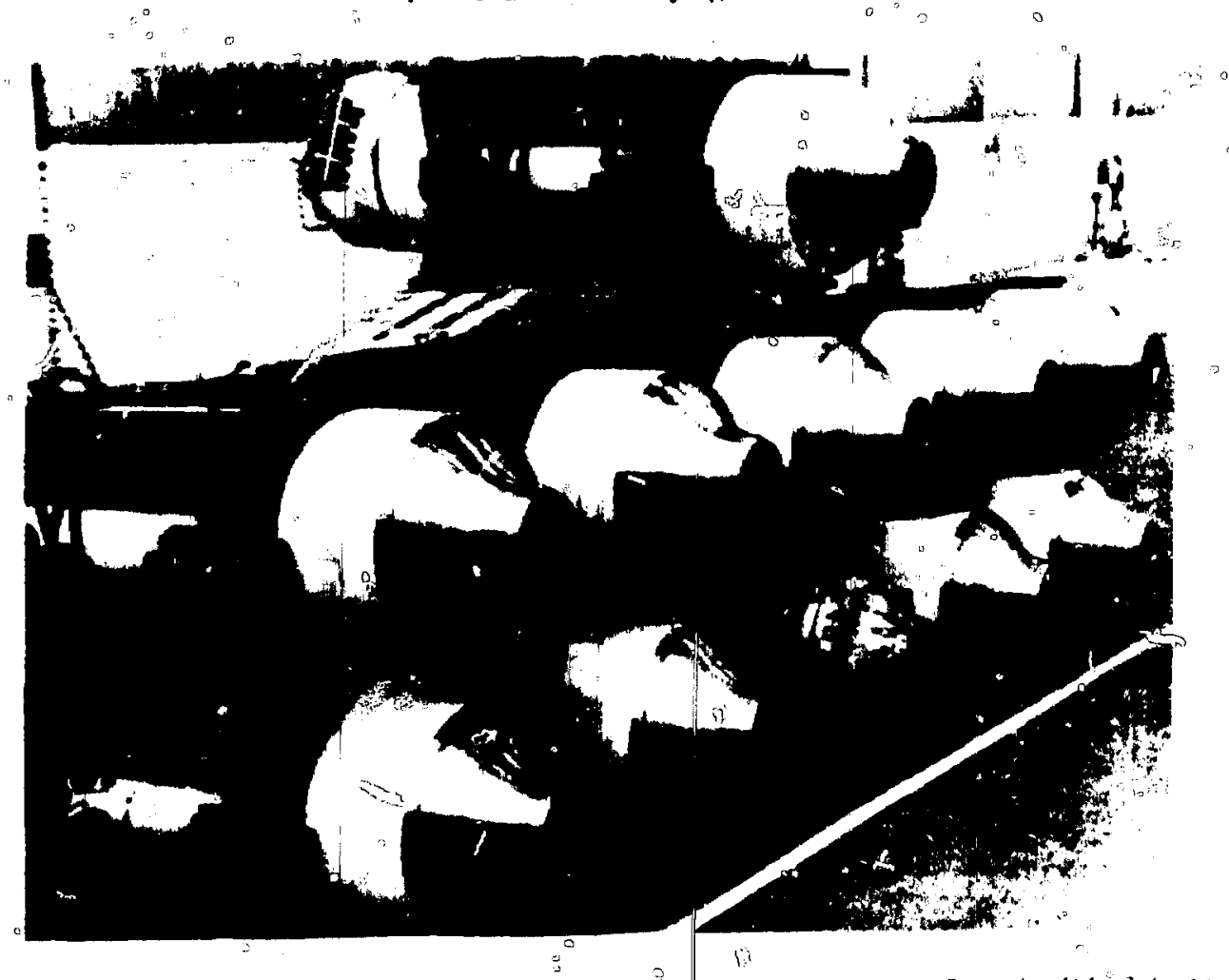

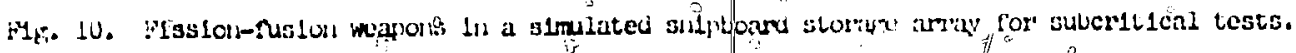




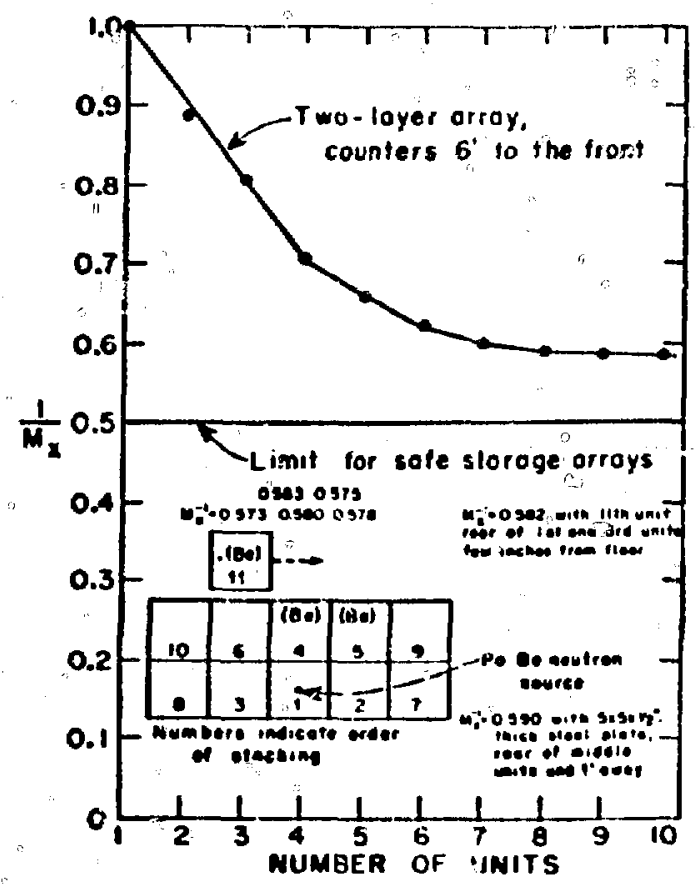

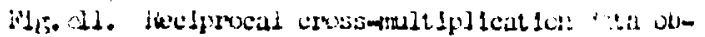

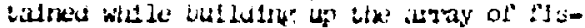

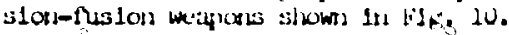

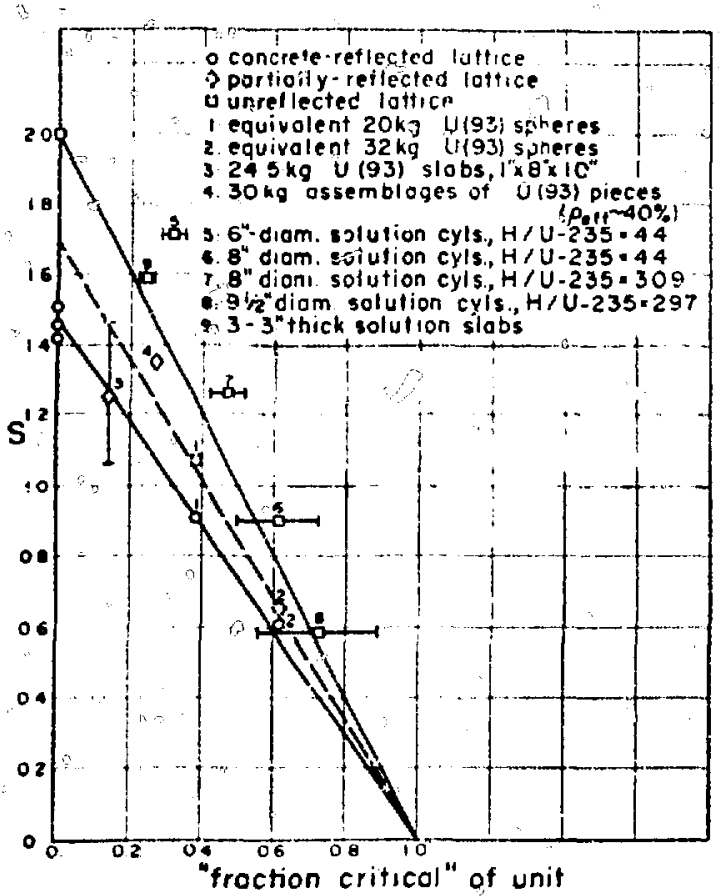

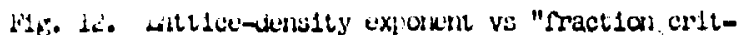
lcal" of as lsolated unt for varjous verreesi of extermal reflection.

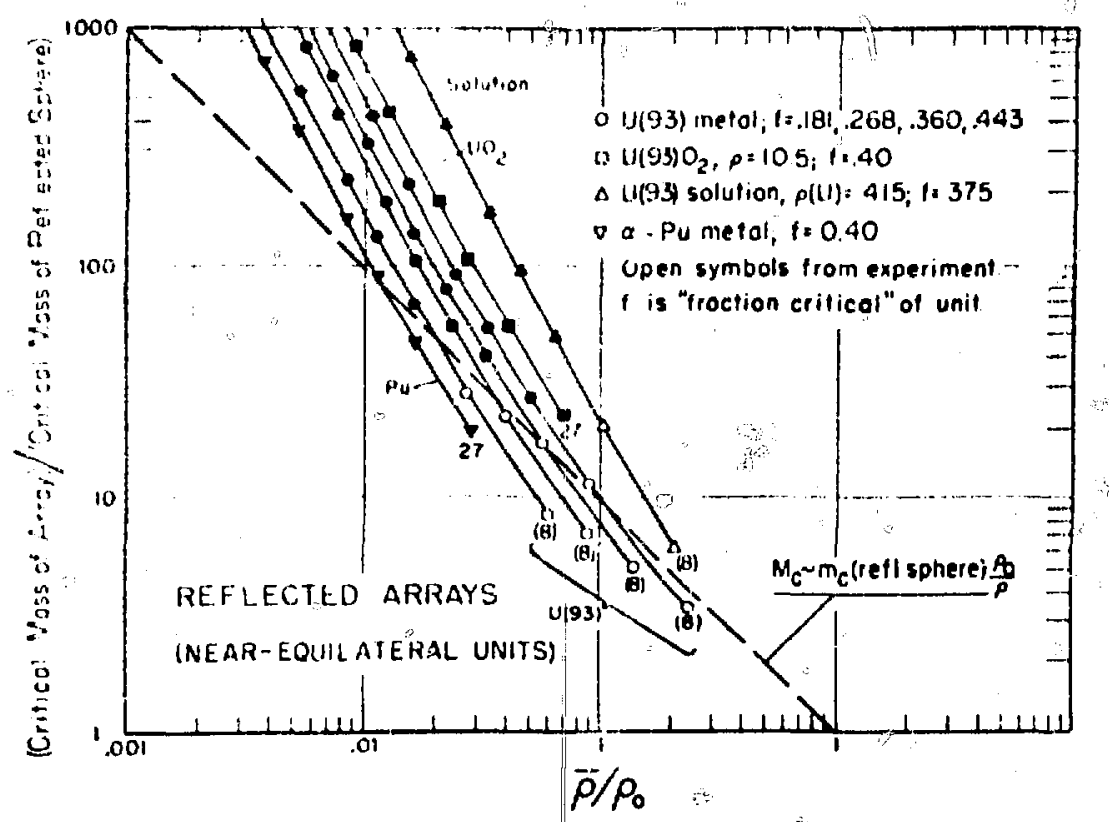

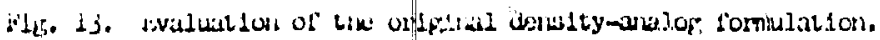




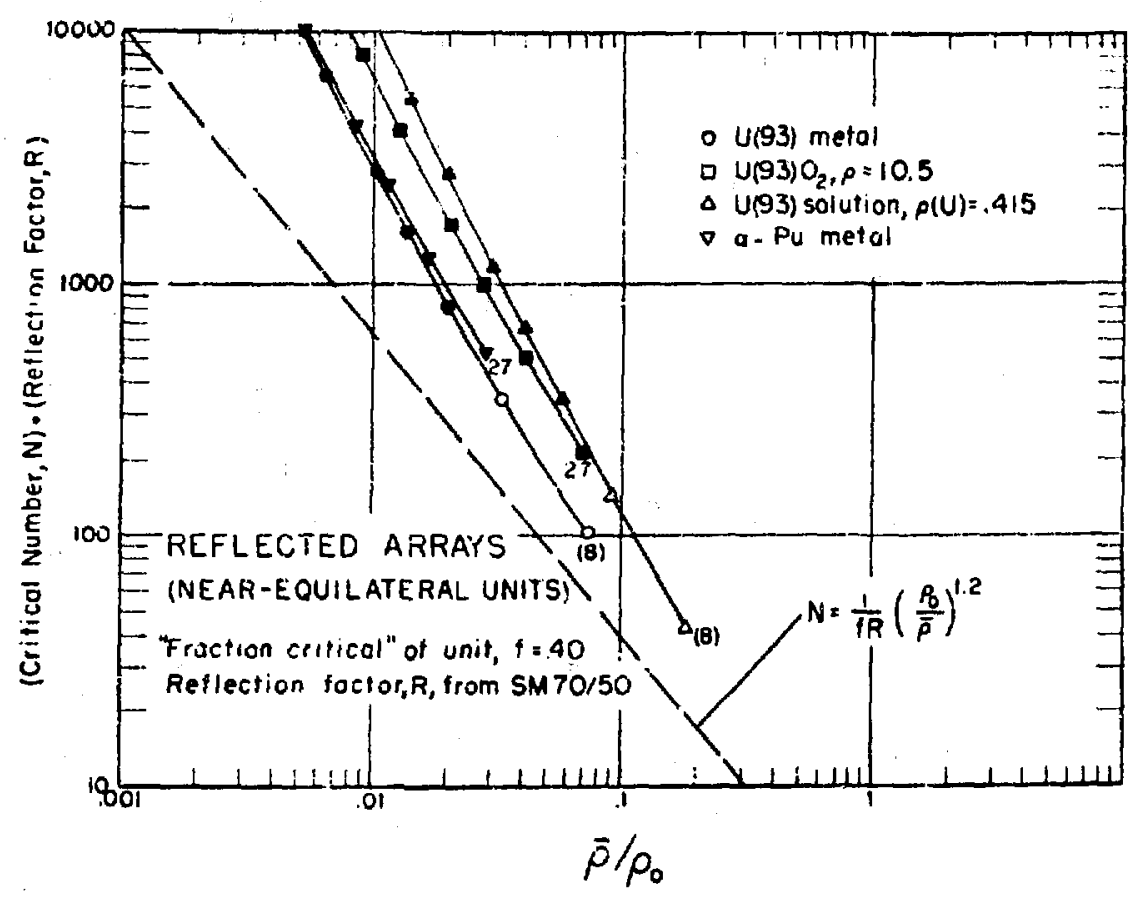

FHg. 14. Livaluation of Smith's mod11icution.

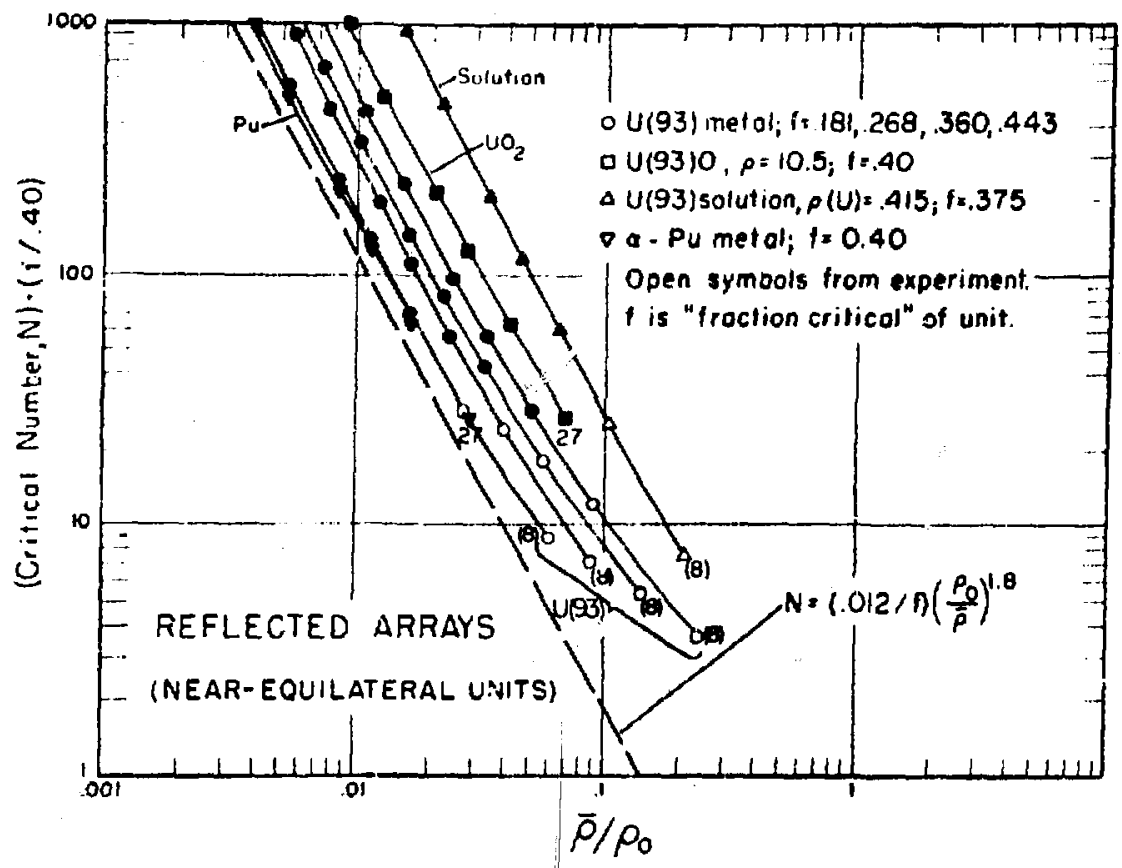

Hg. Is. Livaluation of an adaptation of Ihomas' version. 